\title{
KARDYNAŁ GIOVANNI ANTONIO DAVIA (GIANANTONIO DE VIA) - NUNCJUSZ W RZECZYPOSPOLITEJ (1696-1700)
}

\section{Znaczenie nuncjatury warszawskiej wśród przedstawicielstw dyplomatycznych Stolicy Apostolskiej}

Do najważniejszych kwestii odnoszących się do polityki zagranicznej Rzeczypospolitej w epoce nowożytnej, należały wzajemne relacje ze Stolicą Apostolską. Przez kilka stuleci uwagę polskich polityków na arenie międzynarodowej przyciągał przede wszystkim problem turecki. Zagrożenie, jakie dla Polski niosło Imperium Ottomańskie, nakazywało szukać sojuszników na arenie międzynarodowej, a tutaj naturalnym sprzymierzeńcem była Stolica Apostolska, przez kilka stuleci zabiegająca o bezpieczeństwo Europy zagrożonej ekspansją islamu. Odmiennym problemem była rosnąca w siłę i coraz bardziej ekspansywna Rosja, posługująca się hasłem obrony prawosławia do ingerencji w sprawy wewnętrzne Polski. Inną kwestią związaną z polityką prawosławnej Rosji była sprawa Kościoła unickiego, do której Rzym przywiązywał bardzo dużą wagę, jak również wzajemne relacje pomiędzy katolikami a innowiercami, w tym zwłaszcza protestantami żyjącymi w Polsce.

Stąd też nie dziwi fakt, że stosunkowo wcześnie, bo już w połowie XVI w. utworzone zostało w Rzeczypospolitej stałe przedstawicielstwo Stolicy Apostolskiej - nuncjatura mająca za zadanie utrzymywanie stałych kontaktów z Polską ${ }^{1}$. Jakkolwiek w praktyce funkcjonowania dyplomacji papieskiej, nuncjatura warszawska była nuncjaturą drugiego stopnia (do pierwszego stopnia należały nuncjatury w stolicach mocarstw europejskich, po których nuncjusz kończąc swoją karierę dyplomatyczną otrzymywał kapelusz kardynalski - w Paryżu, Wiedniu, czy Madrycie), to na placówkę warszawską Rzym przysyłał dyplomatów z „najwyższej półki”.

Wynikało to z faktu, że z punktu widzenia papieskiego Sekretariatu Stanu odrębną specyfikę posiadały problemy polityczne w Europie Zachodniej, a odrębną, wymagającą innego przygotowania problemy Europy Wschodniej. Stąd też z biegiem czasu wytworzyła się w Sekretariacie Stanu praktyka, że papiescy dyplomaci obracający się w kręgu spraw Europy Wschodniej podążali wytyczonymi ścieżkami kariery. Swoją służbę dyplomatyczną zaczynali w Kolonii, która najogólniej mówiąc interesowała się niekatolickimi państwami niemieckiego obszaru językowego

\footnotetext{
1 H. D. Wojtyska, Acta Nuntiaturae Polonae, t. 1, Romae 1990.
} 
(pomijając Szwajcarię). Państwami katolickimi z tego obszaru interesowała się placówka wiedeńska².

Nuncjusz na placówce w Kolonii wchodził w problematykę państw protestanckich szczególnie interesując się ich polityką wyznaniową i stosunkiem do Stolicy Apostolskiej. Po tym wejściu w zagadnienia wyznaniowe Europy Środkowo-Wschodniej dyplomatę papieskiego kierowano do Warszawy. W stolicy Rzeczypospolitej kumulowało się szereg zagadnień politycznych tego regionu Europy. Należała do nich, podobnie jak na placówce kolońskiej kwestia zamieszkujących ziemie polskie protestantów. Ale znacznie ważniejsze były inne problemy. Przede wszystkim zagrożenie tureckie, realne nie tylko do pokoju karłowickiego z 1699 r., lecz także później w XVIII w., gdyż Turcja ciągle myślała o odzyskaniu ziem będących kiedyś we władaniu wyznawców Mahometa, a z konieczności oddanych chrześcijanom w pokoju karłowickim.

Innym zagadnieniem absorbującym uwagę Stolicy Apostolskiej było prawosławie. Przez stulecia Rzym dążył do przełamania skutków schizmy wschodniej i osiągnięcia na powrót jedności, a zarazem wciągnięcia Rosji w orbitę świata zachodniego. Zarazem papiestwu zależało na czynnym udziale Rosji w wojnach z Imperium Ottomańskim i imperium carów. Rzym traktował jako ważnego sojusznika w tym konflikcie. Ze względu jednak na wrogi stosunek Moskwy do papiestwa był to sojusznik niepewny, i skłonny do uczestnictwa w wojnach z Turcją za wysoką cenę, którą płacić miała zdaniem Rosji przede wszystkim Rzeczypospolita.

$\mathrm{Z}$ kwestią relacji z prawosławiem połączone było inne zagadnienie, do którego Stolica Apostolska przywiązywała ogromną wagę. Była to sprawa Kościoła unickiego, nierozerwalnie związana z problematyką prawosławia, a odnosząca się do Rzeczypospolitej. Na sprawy Kościoła unickiego dyplomaci papiescy patrzyli nie tylko w relacji z prawosławiem, ale szerzej, na jego funkcjonowanie w wielowyznaniowej Rzeczypospolitej owych czasów.

Po wejściu w problematykę polityczną i religijną Europy Środkowo-Wschodniej w Warszawie nuncjusz, jeśli jego kariera przebiegała w sposób można powiedzieć klasyczny, kierowany był na prestiżową placówkę wiedeńską stanowiącą ukoronowanie jego kariery dyplomatycznej i zwyczajowo kończącej się powrotem do Rzymu i otrzymaniem kapelusza kardynalskiego. Wtedy to były nuncjusz zasiadając w różnych kongregacjach Kurii Rzymskiej służył Stolicy Apostolskiej swoją wiedzą i doświadczeniem.

Wiedeń, stolica Cesarstwa był miejscem, gdzie kumulowały się wszelkie sprawy środkowoeuropejskie i gdzie podejmowano kluczowe decyzje. Nuncjatura wiedeńska sprawowała też niejako merytoryczny nadzór nad innymi nuncjaturami w tym rejonie Europy, monitorując rozwój wydarzeń. Wcześniej taka rola przypadał nuncjaturze weneckiej, lecz w drugiej połowie XVII i XVIII w. rolę tą przejęła

2 W. Kęder, Rola nuncjatury wiedeńskiej w ksztaltowaniu polityki Stolicy Apostolskiej wobec Rzeczypospolitej w okresie pierwszego rozbioru, w: Veritati serviens. Księga pamiątkowa ojcu profesorowi Januszowi Zbudniewkowi, red. Jan Dzięgielewski [i in.], Warszawa 2009, s. 119-130. 
nuncjatura wiedeńska, zaś nuncjatura wenecka czuwała nad przebiegiem poczty dyplomatycznej, co było niezwykle ważnym zagadnieniem dla efektywności działań papieskich dyplomatów ${ }^{3}$.

\section{Początki kariery Giovanniego Antonio Davii}

Giovanni Antonio Davia pochodził z zamożnej rodziny wywodzącej się z miasteczka Domodossola w prowincji Novara, która w połowie XVII w. przeniosła się do Bolonii ${ }^{4}$. Karierę rodzinie Davia zapewnił Pietro Antonio Davia, który dzięki zyskownym operacjom finansowym i handlowym znacznie wzbogacił ród. Jego pozycję wśród bolońskiego patrycjatu ugruntowały udane małżeństwa z członkami rodzin zaliczanych do patrycjatu bolońskiego, gdzie w niedługim czasie rodzina Daviów dostąpiła godności senatorskiej ${ }^{5}$.

Syn Pietro Antonio - Giovanni Battista kontynuował politykę rodu i poprzez małżeństwo z Porzią Ghisleri, ostatnią przedstawicielką możnej, senatorskiej rodziny w Bolonii, która od króla Jana III Sobieskiego otrzymała polski indygenat, znacznie wzmocnił pozycję rodu w Bolonii ${ }^{6}$. Giovanni Battista w małżeństwie z Porzią Ghislieri miał dwóch synów: pierwszym był Virgilio (1649-1703), zaś drugim późniejszy nuncjusz i kardynał Giovanni Antonio. Virgilio, dzięki poślubieniu w 1672 r. pochodzącej ze znakomitego rodu Vittorii Montecuccoli zapewnił rodowi Davia jeszcze wyższy status społeczny od dotychczasowego.

Ponieważ żona Virgilia znajdowała się w bliskim kręgu Marii Beatrice d'Este żony angielskiego pretendenta, Jakuba II Stuarta (króla Anglii w latach 1685-1688, zmarłego w 1702 r.), ród Daviów miał bardzo dobre kontakty z tym królewskim rodem, czego dowodem było nadanie Virgiliowi przez Jakuba II Stuarta tytułu markiza i para Szkocji ${ }^{7}$. Jest wielce prawdopodobne, że te związki z rodem Stuartów zadecydowały w przyszłości o tym, że kardynał Giovanni Antonio Davia został kardynałem-protektorem Szkocji. Virgilio z małżeństwa z Vittorią miał dwóch synów: Giovanniego Battistę (1674-1704), który w życiu kardynała Davii odegra istotną rolę, oraz Francesco (1677-1753).

3 W. Kęder, Stolica Apostolska wobec Rzeczypospolitej w okresie konfederacji barskiej 1767-1773, Opole 2006, s. 83-88.

$4 \mathrm{~W}$ artykule wykorzystano informacje zawarte w korespondencji nuncjusza Davii, znajdującej się w Archiwum Watykańskim, zarówno wydanej drukiem - Acta Nuntiaturae Polonae, t. 37, Giovanni Antonio Davia, cz. 1-2, jak i z rękopisów: Archivio Segreto Vaticano [dalej: ASV], Segreteria di Stato-[dalej: Segr. Stato] Polonia 116-118, jak i literaturze przedmiotu.

5 G. Brizzi, Davia. Famiglia, w: Dizionario Biografico degli Italiani [dalej: DBI], vol. 33, Roma 1987, s. 124-125; Acta Nuntiaturae Polonae, t. 37, Giovanni Antonio Davia (1696-1700), vol. I (13 II 1696 - 28 XII 1696), ed. A(dalbertus) Kęder, s. VII-VIII; G.

Brizzi, Davia Giovanni Antonio, w: DBI, vol. 33, s. 127-128.

6 G. Brizzi, Davia. Famiglia, w: DBI, vol. 33, s. 124.

7 G. Brizzi, Davia. Famiglia..., dz. cyt., s. 124. 
Giovanni Antonio Davia (Gianantonio de Via), drugi po Virgiliu syn Giovanniego Battisty i Porzii, urodził się w Bolonii 13 października 1660 r. Inteligentny i bystry już w młodości wykazywał się zainteresowaniami naukowymi. Na uniwersytetach w Bolonii i Turynie odbył on studia humanistyczne, prawnicze i filozoficzne uwieńczone na uniwersytecie bolońskim doktoratem obojga praw, co otwierało przed nim perspektywy ewentualnej kariery kościelnej. Po ukończeniu studiów młody Giovanni Antonio działał jako prawnik w rodzinnej Boloni. W tym też okresie rozwijał swoje pasje naukowe szczególnie interesując się matematyką i astronomią, jak również prowadząc korespondencję z luminarzami naukowymi owej epoki, do których zaliczali się m.in. Marcello Malpighi, G. Montanari i Ugo Gozzadini ${ }^{8}$.

W 1681 r. Giovanni Antonio odbył podróż naukową do Londynu, biorąc także udział w obradach Royal Society9. Po powrocie do Italii w tym samym roku za namową Virgilia, który był senatorem w Bolonii, brał czynny udział w życiu politycznym miasta. W grudniu 1681 r. był już urzędnikiem miejskim, zaś w 1683 r. został mianowany zwierzchnikiem Castel San Pietro w okręgu bolońskim.

Niespokojny duch młodego Davii dał jednak o sobie znów znać i w 1684 r. wziął udział w wojnie, jaką Liga Święta toczyła z Imperium Ottomańskim, wyprawiając się z wojskami toskańskimi wspierającymi armię wenecką jako ,ingegnere volontario" na Moreę. Po wypłynięciu z Neapolu latem 1684 r. Giovanni Antonio Davia dotarł z oddziałami chrześcijańskimi do celu, biorąc udział w walkach z Turkami. Morea została zdobyta przez oddziały weneckie później, w 1687 r. Po kilkumiesięcznym epizodzie wojennym Davia powrócił do Italii, ale nie do Bolonii, lecz wyjechał do Rzymu, gdzie rozwijał swoje zainteresowania naukowe, prowadząc także korespondencję ze współczesnymi mu uczonymi, jak również kolekcjonując monety i medale, których zgromadził poważne zbiory.

W 1687 r. miało miejsce wydarzenie, które wywarło decydujący wpływ na jego dalsze losy: Giovanni Antonio został przedstawiony papieżowi Innocentemu XI, który zachęcił go do wstąpienia do stanu kapłańskiego i do papieskiej służby dyplomatycznej ${ }^{10}$. W życiorysach Davii o tym decydującym momencie pisze się jedynie, iż został przedstawiony papieżowi, z którego strony padła powyższa propozycja ${ }^{11}$. Ale niełatwo było naonczas dostać się do pałaców apostolskich i być przedstawionym samemu papieżowi. Również niełatwo było otrzymać możliwość robienia kariery w służbie dyplomatycznej uważanej powszechnie za bardzo atrakcyjną. Nuncjusz papieski otrzymując nominację zostawał arcybiskupem in partibus infidelium. Zarazem po skończeniu kariery dyplomatycznej, zazwyczaj kierowany był do pracy w Kurii rzymskiej, gdzie służył swoją wiedzą i doświadczeniem zdobytym na placówkach dyplomatycznych, a nierzadko zwieńczeniem kariery kurialnej był

\footnotetext{
8 J. L. Heilbron, The Sun in the Church: Catedrals as Solar Observatories, Harvard 1999, s. 204-209, 216.

9 T. Birtch, History of the Royal Society, vol. 4, London 1757, s. 94.

10 D. Squicciarini, Nunzi apostolici a Vienna, Città del Vaticano 1998, s. 152.

11 G. Brizzi, Davia Giovanni Antonio, w: DBI, vol. 33, s. 127.
} 
kapelusz kardynalski. Musiała zatem zadziałać protekcja, umożliwiająca Davii tak szybką karierę.

Dlatego też można domniemywać, że za decyzją wyjazdu Davii do Rzymu kryły się skonkretyzowane już plany, lecz trudno jest znaleźć konkretne ślady wiodące do protektorów młodego Giovanniego Antonio. Najbardziej wiarygodne tropy mogłyby prowadzić do potężnego i wpływowego rodu Odescalchich, z którego wywodził się papież Innocenty XI (1676-1689), który w latach 1650-1656 był biskupem Novary, opodal której leżała rodzinna posiadłość Daviów w Domodossola i którzy przyjaźnili się z członkami tego książęcego rodu zaliczanego do czarnej arystokracji papieskiej.

Obojętnie jednak kto protegował Giovanniego Antonio, jego kariera dyplomatyczna zaczęła toczyć się szybko. Już 18 lipca 1687 r. Davia otrzymał nominację na internuncjaturę apostolską w Brukseli ${ }^{12}$. Jakkolwiek internuncjatura to placówka trzeciej rangi, to jednak internuncjatura w Brukseli miała bardzo istotne znaczenie obejmując swoim zainteresowaniem Anglię, Szkocję, Irlandię oraz Holandię. Być może o nominacji Davii akurat na tę placówkę przesądziły kontakty rodu Daviów ze Stuartami.

W Brukseli Davia spotkał się z sytuacją wymagającą umiejętności dyplomatycznego lawirowania, a związaną z konfliktami narosłymi wokół jansenizmu, który dla papieskich dyplomatów w owym czasie był wyjątkowo ciężkim problemem, z którym musieli się uporać z jednej, a skomplikowanymi stosunkami pomiędzy Stolicą Apostolską a Francją, rzutującymi także na sprawy belgijskie. Z okresem pobytu G. A. Davii na placówce brukselskiej łączyły się w późniejszym okresie plotki, oskarżające go o nadmierne sympatie do jansenistów ${ }^{13}$.

Podejrzenia Giovanniego Antonio Davii o sprzyjanie jansenistom, głównie w czasie, gdy przebywał w Brukseli ciągnęła się szereg lat komplikując karierę tego papieskiego dyplomaty. Po śmierci G. A. Davii znane pismo jansenistów, „Nouvelles Ecclésiastiques" ujawniło, iż Davia korespondował z jednym z najwybitniejszych przedstawicieli jansenistów, biskupem Montpellier, Colbertem de Croissy. Przeciwko tym informacjom energicznie protestował przyjaciel zarówno Giovanniego Antonio Davii, jak i jego rodziny, a pochodzący również z Bolonii jego ziomek - Prospero Lambertini, późniejszy papież Benedykt XIV ${ }^{14}$. W Brukseli Davia przebywał do 24 kwietnia 1690 r., lecz opinię musiał pomimo plotek zyskać pozytywną, gdyż skierowano go na kolejną placówkę w Kolonii.

12 L. Cardella, Memorie storiche de' cardinali della Santa Romana Chiesa scritte da ..., t. 8, Roma 1744, s. 119-121.

${ }_{13}$ M. Pieroni Francini, Da Clemente XI a Benedetto XIV; il caso Davia, „Rivista di Storia della Chiesa in Italia" 37 (1983), s. 445.

14 F. Petrucelli della Gattina, Histoire diplomatique des conclaves, vol. IV, Bruxelles 1866, s. 6, 71; L. Pastor, „Storia dei papi dalla fine del medio evo”, vol. XV „Storia dei papi nel periodo dell' Assolutismo”. Vol. XV „Dall'elezione di Clemente XI sino alla morte di Clemente XII (1700-1740)", s. 652-654. 
Desygnacja Davii na placówkę kolońską łączyła się, jak to zwyczajowo z nuncjuszami bywało z nominacją na arcybiskupa tytularnego. W dniu 21 czerwca 1690 r. Giovanni Antonio Davia otrzymał z rąk papieża Klemensa XI nominację na tytularnego arcybiskupa Teb z dyspensą, gdyż ani nie był w wieku kanonicznym, ani też nie miał święceń. W miesiąc później, w lipcu tego roku został skierowany jako nuncjusz papieski do Kolonii, na której to placówce przebywał przez sześć lat, do 24 kwietnia 1696 r. $^{15}$

\section{Nuncjusz Davia a elekcja Augusta II Mocnego}

Na początku 1696 r. Davia otrzymał nominację na nuncjusza w Rzeczypospolitej, a w Warszawie pojawił się latem tego roku. Jak pisał w biogramie Davii Julian Bartoszewski „Pierwsze wrażenie, jakie [Davia] sprawił na panach, ukazaniem się swojem było bardzo dla niego przychylne" ${ }^{16}$. Cytował też Bartoszewski opinię Załuskiego: „Widziałem nuncjusza, pisze Jędrzej Chryzostom Załuski; jeżeli tyle pokaże szczerości, co zdolności i rozumu, możem sobie wiele dobrego powinszować... Zgadywał zdaje się charakter nuncyusza Załuski, bo Davia miał tylko pozór dobroduszności, ale w rzeczy samej był to człowiek namiętny i chytry" ${ }^{\prime 1}$.

Jakkolwiek w trakcie czteroletniego pobytu Davii na placówce warszawskiej, nuncjusz stanął wobec wielu problemów zarówno natury wewnętrznej, jak i zagranicznej, to niewątpliwie sprawą najbardziej doniosłą, jak i tą, która odbiła się najgłośniejszym echem zarówno w kraju, jak i za granicą była kwestia ewentualnego zaangażowania nuncjusza w elekcję elektora Saksonii, Fryderyka Augusta Wettyna, późniejszego króla Augusta II Mocnego. Jego wybór przyniósł tragiczne następstwa dla Rzeczypospolitej związane zarówno z polityką wewnętrzną, która doprowadziła do zawiązania konfederacji tarnogrodzkiej, jak i polityką zagraniczną gdzie wejście króla w trzecią wojnę północną przyniosło dla Rzeczypospolitej opłakane skutki.

Po śmierci króla Jana III Sobieskiego o polską koronę rywalizowało wielu kandydatów, w tym przede wszystkim Ludwik Bourbon książę de Conti, skłóceni ze sobą synowie króla Jana III, z których największe szanse miał Jakub Sobieski, Don Livio Odescalchi, Karol Neuburski, margrabia badeński Ludwik Wilhelm i inni. Kandydatura Wettyna pojawiła się bardzo późno i wzbudziła szereg kontrowersji i podejrzeń. Władca Saksonii był protestantem, a królem Rzeczypospolitej mógł zostać tylko katolik. Dodatkowo Fryderyk August Wettyn był władcą Saksonii - kolebki protestantyzmu i jego poddani z niedowierzaniem i niechęcią przyjęli informację o staraniach elektora o polską koronę, co połączone być musiało z jego konwersją na katolicyzm.

15 Acta Nuntiaturae Polonae, t. 37, Giovanni Antonio Davia (1696-1700), vol. 1 (13 II 169628 XII 1696)..., dz. cyt., s. VIII-IX.

16 Jul. B. [J. Bartoszewski], Davia (Jan Antoni de Via), w: Encyklopedyja Powszechna, t. 6, Warszawa 1861, s. 815.

17 Jul. B. [J. Bartoszewski], Davia (Jan Antoni de Via)..., dz. cyt. 
Wrogo na starania Wettyna, zapatrywali się francuscy dyplomaci reprezentujący interesy najpoważniejszego z kandydatów, księcia de Conti, forsowanego na tron polski przez króla Ludwika XIV, a podobnie reagowało stronnictwo francuskie. Również niechętnie widział nowego konkurenta wspierany w swoich staraniach o koronę książę Jakub Sobieski, a także inni kandydaci. Zwycięstwo w staraniach o koronę Wettyna, spowodowało dla francuskich dyplomatów łatwe do przewidzenia konsekwencje: Melhior de Polignac popadł w niełaskę i zesłany został w $1698 \mathrm{r}$. do opactwa w Bon-Port, którego Polignac był opatem komendatoryjnym.

W zaistniałej sytuacji nie tylko po elekcji, ale jeszcze w trakcie rywalizacji o koronę przeciwnicy Wettyna zaczęli winą za swoją spodziewaną klęskę obarczać papieskiego nuncjusza. Zarówno Polignac, jak i stojący na czele stronnictwa francuskiego kardynał Radziejowsk, i przyczyn klęski Contiego dopatrywali się w m.in. działaniach nuncjusza Davii, który ich zdaniem zbyt pochopnie uwierzytelnił konwersję Fryderyka Augusta na katolicyzm w Baden z 2 VI 1697 r. ${ }^{18}$ Zarazem francuscy dyplomaci i część polskich polityków wręcz oskarżała nuncjusza Davię o skłonienie Fryderyka Augusta Wettyna do kandydowania o polską koronę.

Skąd ich zdaniem miała wynikać przychylność nuncjusza dla saskiego kandydata? Według nich wiązało się to z uwolnieniem z tureckiej niewoli bratanka nuncjusza, a syna Virgilia, Giovanniego Battisty. Nuncjusz Davia był bardzo zżyty z tym starszym synem Virgilia, który towarzyszył wujowi na placówkach dyplomatycznych w Brukseli i Kolonii. Później, wykorzystując pokrewieństwo z cesarskim feldmarszałkiem Enea Silvio Caprarą, Giovanni Battista brał udział w walkach z Turkami na terenie Węgier. W trakcie działań wojennych dostał się do tureckiej niewoli i zamknięty w zamku Siedmiu Baszt przebywał w niej przez trzy lata ${ }^{19}$.

Długotrwałe, a prowadzone różnymi kanałami dyplomatycznymi zabiegi rodziny Daviów o wydobycie go z tureckiej niewoli, przez dłuższy czas nie przynosiły rezultatów. Giovanni Antonio Davia w sprawie bratanka interweniował poprzez bratową, hrabinę d'Altamonte, która była damą honorową królowej angielskiej na dworze króla Francji Ludwika XIV. Król nakazał swojemu ambasadorowi w Polsce, Melhiorowi de Polignac zabiegać u Turków o uwolnienie młodego Davii z niewoli. Ponieważ Turcy odmówili wydania Giovanniego Battisty Davii, misja Polignaca zakończyła się jednak niepowodzeniem, przyczyniając się jednocześnie do ochłodzenia stosunków pomiędzy nuncjuszem a ambasadorem francuskim.

Sprawa uwolnienia z niewoli syna Virgilia przybrała raptem pomyślny obrót w chwili, gdy arcybiskup Davia dowiedział się, że elektor saski, a późniejszy król

18 ASV, Segr. Stato, Polonia 118, f. 485r-485v, nuncjusz Giovanni Antonio Davia do kardynała Fabrizio Spasy, Varsavia 24 IX 1697. Zastosowane skróty według: „Indice dei Fondie relativi mezzi descrizione e di ricerca", Città del Vaticano 2002; K. Piwarski, Pierwsze stosunki Augusta II ze Stolica Apostolską. Nieznana karta z dziejów dyplomacji polskiej, Warszawa 1937, s. 8.

19 ASV, Segr. Stato, Polonia 118, f. 360r-360v, nuncjusz Giovanni Antonio Davia do kardynała Fabrizio Spasy, Varsavia 11 VII 1697. 
polski Fryderyk August prowadzący wówczas działania wojenne na Węgrzech, w walkach pod Temeszwarem wziął do niewoli znacznego tureckiego paszę. Nuncjusz prosił elektora, aby ten wyraził zgodę na wymianę jego jeńca na Giovanniego Battistę i dzięki zgodzie Fryderyka Augusta, młody Davia po trzech latach niewoli dzięki władcy Saksonii odzyskał wolność. Niewątpliwie, elektor saski, zyskał dzięki temu wdzięczność papieskiego nuncjusza w Polsce, co rywalom Wettyna dało okazję do pomawiania nuncjusza o stronniczość na polu elekcyjnym ${ }^{20}$.

Istotną jest odpowiedź na pytanie, czy oskarżenia te były słuszne, gdyż papieskie instrukcje przesłane nuncjuszowi na okoliczność elekcji nakazywały pilnowanie, aby kandydatem do korony był katolik i zachowanie neutralności ${ }^{21}$. Jakkolwiek sugestie takie pojawiają się w szeregu wystąpień dyplomatów francuskich, jak i ich polskich stronników z kardynałem Michałem Radziejowskim na czele, to nie ma jasnych dowodów, wskazujących na bezpośrednie zaangażowanie nuncjusza w elekcję Fryderyka Augusta22.

Jeśli mówimy o kandydowaniu przez Fryderyka Augusta Wettyna do korony polskiej i reakcji dyplomatów papieskich, i Stolicy Apostolskiej na tę kandydaturę, to należy wspomnieć tu o jednym, bardzo ważnym aspekcie tej sprawy w żaden sposób nie podnoszonym ani przez francuskich dyplomatów, ani przez kardynała Radziejowskiego, ani też innych polskich polityków wypowiadających się w tej sprawie. Mianowicie z punktu widzenia Rzymu kandydatura do tronu polskiego elektora saskiego była ze wszech miar pożądana i Stolica Apostolska zapatrywała się na nią bardzo przychylnie, gdyż wiązała się z koniecznością konwersji władcy Saksonii na katolicyzm. W Rzymie łączono z nią wielkie nadzieje na rekatolizację Saksonii, nie wspominając o propagandowym znaczeniu faktu, iż władca Saksonii - kolebki luteranizmu powraca na łono Kościoła katolickiego.

Dalszy bieg wypadków pokazał, że nadzieje te były nierealne. Jakkolwiek Fryderyk August dokonał w Baden konwersji na katolicyzm (z formalnymi błędami aby w razie niepowodzeń na polu elekcyjnym wycofać się), to jego żona Krystyna Eberhardyna z Hohenzollernów odmówiła przejścia na katolicyzm, nie była koronowana na królową, jak również nigdy do Polski nie przyjechała. Również w Saksonii, jakkolwiek poprawiono los katolików, nie było w większej skali konwersji poddanych elektora. Nie zmienia to w niczym faktu, że w Rzymie fakt konwersji na katolicyzm elektora przyjęto z zadowoleniem przychylnie traktując zarówno Augusta II Mocnego, jak i później jego syna, Augusta III Sasa.

20 ASV, Segr. Stato, Polonia 117, f. 198r-201v, nuncjusz Giovanni Antonio Davia do kardynała Fabrizio Spasy, Varsavia 18 VII 1697.

${ }^{21}$ Acta Nuntiaturae Polonae, t. 37, Giovanni Antonio Davia (1696-1700), vol. 2 (23 VI 1696-18 V 1697), ed. A(dalbertus) Kęder, Cracoviae 2010, s. 312-313, kardynał sekretarz stanu Fabricius Spada do nuncjusza w Polsce, arcybiskupa Giovanniego Antonio Davii, Roma 9 III 1697.

22 ASV, Segr. Stato, Polonia 117, f. 172r-174v, nuncjusz Giovanni Antonio Davia do kardynała Fabrizio Spady, Varsavia 4 VII 1697. 


\section{Giovanni Antonio Davia na placówce warszawskiej}

Czteroletni okres, na jaki przypadła misja nuncjusza Davii w Rzeczypospolitej był czasem niezwykle burzliwym, i to zarówno w sprawach wewnętrznych, jak i zagranicznych. Zjawiwszy się w Warszawie, zaraz po śmierci króla Jana III Sobieskiego, nuncjusz trafił od razu na apogeum sporów ze Stolicą Apostolską a związanych $\mathrm{z}$ obsadą opactw komendatoryjnych, jak również uprawnieniami nuncjatury, a zwłaszcza sprawą trybunału nuncjatury, na uprawnienia którego niechętnie patrzyła nie tylko szlachta, lecz i dygnitarze duchowni, jak również kwestionowanymi przez nich uprawnieniami nuncjuszy apostolskich ${ }^{23}$.

W centrum zainteresowania Rzymu znajdowała się też rodzina Sobieskich - zwycięzcy spod Wiednia, którą papiestwo otaczało opieką. Stąd też Davia śledził losy skłóconych ze sobą i matką - królową Marysieńką, synów Jana III, jak również jednego z kandydatów do tronu, męża Kunegundy Sobieskiej, elektora bawarskiego Maksymiliana II Emanuela ${ }^{24}$. Oprócz sporów związanych z elekcją, ród Sobieskich trapiły też konflikty majątkowe, dotyczące wielkiego spadku po słynącym z dużej zapobiegliwości finansowej królu. Dlatego też nuncjusz drobiazgowo informował Sekretariat Stanu o stanie majątkowym rodu Sobieskich, jak również o kolejnych etapach konfliktu, w który zamieszani byli także najwięksi dygnitarze Rzeczypospolitej ${ }^{25}$. Wdzięczność i zainteresowanie Stolicy Apostolskiej dla rodziny zwycięzcy spod Wiednia towarzyszyć będzie rodowi Sobieskich także w późniejszych latach m.in. przy okazji pobytu wdowy po królu Janie III, królowej Marii Kazimiery w Rzymie, czy też przy sprawie konfliktu synów Jana III Sobieskiego z królem Augustem II Mocnym, gdzie członków rodu Sobieskich ciągle otaczała opieka papieskich dyplomatów ${ }^{26}$.

Do innych wydarzeń absorbujących uwagę nuncjusza podczas jego pobytu w Warszawie, należał konflikt Sapiehów zarówno z hierarchią kościelną na Litwie, w tym z biskupem wileńskim Kazimierzem Brzostowskim, a odnoszący się do bezprawnego obciążenia przez Sapiehów dóbr kościelnych na Litwie. Nuncjusz Davia po swoim przyjeździe do Polski podjął się misji mediacyjnej pomiędzy skonfliktowanymi stronami i mimo początkowych niepowodzeń, jakich doznał,

23 ASV, Segr. Stato, Polonia 116, f. 326 r., Kopia listu Jana III Sobieskiego do nuncjusza G. A. Davii, Varsavia, V 1696; f. 326r-326v. Nuncjusz G. A. Davia do kardynała sekretarza stanu Fabrizio Spady, Roma 3 VII 1696; ASV, Segr. Stato, Polonia 112, f. 43v-44r. Kardynał sekretarz stanu Fabrizio Spada do nuncjusza G. A. Davii, Roma 30 VI 1696.

24 Z. Libiszowska, Ród Sobieskich w Europie po śmierci Jana III, „Sobótka” 35 (1980), nr 2, s. 360; E. Jastrzębska, Maria Kazimiera Sobieska wobec kandydatury syna Jakuba podczas bezkrólewia w świetle depesz ambasadora Polignaca (1696-1697), „Sobótka” 35 (1980), s. 351-354.

25 Z. Libiszowska, Ród Sobieskich..., dz. cyt., s. 360; E. Jastrzębska, Maria Kazimiera..., dz. cyt., s. 351-354; S. Orszulik, Polemika wokół kandydatury Sobieskich do korony w okresie bezkrólewia 1696/1697, „Sobótka” 35 (1980), nr 2, s. 342-343.

26 W. Kęder, Jasna Góra wobec przemian politycznych w Rzeczypospolitej w latach 1661-1813, „Studia Claromontana” 13 (1993), s. 106. 
ostatecznie jego starania uwieńczone zostały powodzeniem. Innym wydarzeniem z zakresu polityki wewnętrznej, które przykuwało uwagę papieskiego dyplomaty w zasadzie przez cały czas pobytu w Rzeczypospolitej był konflikt rodu Sapiehów ze szlachtą i magnaterią litewską, w tym z rodem Kryszpinów, jak również hierarchią kościelną na Litwie, m.in. zakończony po kilku latach tragiczną bitwą pod Olkiennikami.

Poza wewnętrznymi sprawami Rzeczypospolitej uwagę nuncjusza z oczywistych względów przykuwała wojna z Turcją, zakończona pokojem karłowickim w 1699 r. Rzeczpospolita w tej wojnie odgrywała drugorzędną rolę, ale niezwykle istotne dla Rzeczpospolitej było odzyskanie ziem utraconych na rzecz Turcji w 1672 r. i w latach późniejszych. Z problematyką turecką ściśle wiązały się zagadnienia rosyjskie: ekspansja Rosji na arenie międzynarodowej, jak i koegzystencja z prawosławiem. Tutaj nuncjusz pilnował interesów i pozycji Kościoła katolickiego w Polsce, zwracając także uwagę na kondycję Kościoła unickiego.

\section{Kardynat Davia w Wiedniu i w Rzymie}

Późną wiosną 1700 r. Giovanni Antonio Davia zakończył swoją misję dyplomatyczną w Rzeczypospolitej i skierowany został na prestiżową placówkę w stolicy Cesarstwa, w Wiedniu. Wcześniej, 10 maja 1698 r. Davia otrzymał personalną nominację na arcybiskupa Rimini. Nominację arcybiskup Davia otrzymał w trudnym momencie zaostrzenia wzajemnych relacji pomiędzy Cesarstwem a Stolicą Apostolską. Spowodowane to było oprotestowaniem w $1701 \mathrm{r}$. przez papieża Klemensa XI, koronacji elektora brandenburskiego na króla w Prusiech (Rzeczpospolita, której ta sprawa głównie dotyczyła nie zareagowała). Eskalacja napięcia nastąpiła w 1705 r., kiedy to w 1705 r. wynikły spory wokół obsady tronu hiszpańskiego. Po odmowie cesarza na przyjęcie nuncjusza nadzwyczajnego Horazio Filippo Spady, do opuszczenia Rzymu zmuszony został cesarski ambasador Leopold von Lamberg. W ramach retorsji nuncjusz Giovanni Antonio Davia, otrzymawszy trzy dni na wyjazd ze stolicy Austrii opuścił Wiedeń 15 lipca 1705 r.

Jak pisał o przyczynach wydalenia G. A. Davii Ludwig baron von Pastor „,[Davia]Benchè uomo distinto, combattente prima con la spada contro $i$ turchi ed entrato poi per consiglio di Innocenzo XI nella carriera ecclesiastica, egli cadde a Vienna in disgrazia, perchè secondo l'istruzione papale del 1705 non volle riconoscere l'arciduca Carlo come re di Spagna"27.

Po powrocie do Italii arcybiskup Davia objął w zarząd swoją diecezję w Rimini. W pamięci jej mieszkańców zapisał się jako sprawny administrator przeprowadzając m.in. dwa synody diecezjalne w 1711 i $1724^{28}$. W tym też czasie zarówno arcybisku-

27 L. Pastor, „Storia dei papi dalla fine del medio evo”, vol. 15, „Storia dei papi nel periodo dell'Assolutismo”. Vol. XV „,Dall'elezione di Clemente XI sino alla morte di Clemente XII (1700-1740)", Roma 1932, s. 268.

28 Synodus dioecesanus Ecclesiae Arminensis ab il. et rev. D. I. A. Devia... habita in Ecclesia 
powi Davii, jak i biskupowi Valenti Gonzadze, Rimini zawdzięczało w tym czasie znaczne ożywienie kulturalne ${ }^{29}$. Obowiązki ordynariusza diecezji Giovanni Antonio Davia łączył jak wcześniej ze swoimi zainteresowaniami naukowymi, współpracując z uczonymi zarówno w kraju, jak i za granicą, w tym m.in. z E. Manfredim oraz F. Bianchinim, z którymi wymieniał się rezultatami obserwacji astronomicznych i prowadzonych doświadczeń naukowych.

Davię łączyły w owym czasie węzły przyjaźni nie tylko z Manfredim i Bianchim, lecz także z jednym z najbardziej błyskotliwych intelektualistów tej doby w Europie, jakim był Prospero Lambertini, późniejszy papież Benedykt XIV: „the asteronomer Eustachio Manfredi, and cardinal Giovanantonio Davia, who was also a passionato scientific amateur, secret Copernican, and dangerously close to jansenist heresy"30.

W dniu 18 maja 1712 r. Giovanni Antonio Davia, został przez papieża Klemensa XI (1700-1721) mianowany kardynałem prezbiterem. W sierpniu 1715 otrzymał nominację na papieskiego legata w Urbino, zaś 12 kwietnia 1717 r. na legata w Romanii ${ }^{31}$. Dnia 7 grudnia 1726 r. kardynał Davia z powodu podagry zrezygnował z pełnienia swoich obowiązków administratora diecezji Rimini i powrócił do Rzymu. W trakcie pobytu w Rzymie, kardynał aktywnie pracował w kurii będąc członkiem szeregu Kongregacji (Sacra Congregazione del S. Offizio, Sacra Congregazione dei Vescovi e Regolari, Sacra Congregazione della Immunità, Sacra Congreagzione di Propaganda Fide). Był również kardynałem-protektorem Anglii i Polski reprezentując ich interesy wobec Stolicy Świętej. Również przy Stolicy Apostolskiej reprezentował interesy Bolonii oraz zakonu cystersów ${ }^{32}$.

Kardynał Davia brał udział aktywny udział w konklawe w 1721, 1724 i 1730 r. odgrywając na nich ważną rolę. Na konklawe w 1721 był wymienianym wśród cesarskich kandydatów na tron św. Piotra, na który wybrano papieża Innocentego XIII. Z kolei na konklawe w 1730 r. również Giovanni Antonio Davia znalazł się wśród kandydatów, lecz w tym wypadku istotną rolę odegrały plotki oskarżające go o sprzyjanie jansenistom ${ }^{33}$.

Kardynał Giovanni Antonio Davia zmarł 11 stycznia 1740 r. w Rzymie, w którym spędził ostatnie lata swojego życia. Pochowany został w swojej tytularnej bazylice San Lorenzo in Lucina przy Via del Corso w kaplicy błogosławionego Francisz-

cathedrali... anno 1711, Rimini [1713]; Synodus dioecesana Ecclesiae Arminensis ab Em. et Rev. S. R. E. Cardinali J. A. Davia, Rimini 1724.

29 La città di Rimini: http://www.queen.it/citta/rimini/storia [dostęp: 20 VI 2004 r.].

30 Benedict XIV and the Enlightenemt Art., Scince and Spirituality, ed. R. Messbarger, Ch.M.S. Johns, P. Gavitt, Toronto, Buffalo, London 2016, s. 28-29.

31 Ch. Weber, Legati e governatori dello Stato Pontificio (1550-1809), Roma 1994. Publicazioni degli Archivi di Stato, Sussidi 7, s. 370, 419, 613.

32 L. Cardella, Memorie storiche de' cardinali della Santa Romana Chiesa scritte da ..., t. 8, Roma 1744, s. 121.

33 G. Brizzi, Davia Giovanni Antonio, w: DBI, vol. 33, s. 127-128. 
ka Carracciolo. Papież Benedykt XIV (Prospero Lambertini), przyjaciel kardynała Davii w drugim roku swojego pontyfikatu, w 1742 r. w tejże bazylice San Lorenzo in Lucina w przejściu prawej nawy prowadzącym do zakrystii bazyliki ufundował ku jego pamięci popiersie, pod którym umieszczona tablica sławi zasługi kardynała Giovanniego Antonio Davii związane z jego działalnością zarówno na niwie kościelnej, jak i politycznej, kładąc akcent na jego zdolności dyplomatyczne.

\section{BIBLIOGRAFIA}

\section{Źródla archiwalne:}

\section{Archivio Segreto Vaticano:}

Segreteria di Stato Polonia, sygn. 116-118.

\section{Źródła drukowane:}

Acta Nuntiaturae Polonae, t. 37, Giovanni Antonio Davia (1696-1700), vol. 1 (13 II 1696-28 XII 1696) ed. A(dalbertus) Kęder, Cracoviae 2004.

Acta Nuntiaturae Polonae, t. 37, Giovanni Antonio Davia (1696-1700), vol. 2 (23 VI 1696-18V 1697) ed. A(dalbertus) Kęder, Cracoviae 2010.

\section{Opracowania:}

Benedict XIV and the Enlightenemt Art., Scince and Spirituality, Ed. R. Messbarger, Ch. M. S. Johns, P. Gavitt, Toronto, Buffalo, London 2016.

Birtch T., History of the Royal Society, vol. 4, London 1757.

Brizzi G., Davia Giovanni Antonio, w: Dizionario Biografico degli Italiani, vol. 33, Roma 1987, s. 127-128.

Brizzi G., Davia. Famiglia, w: Dizionario Biografico degli Italiani, vol. 33, Roma 1987, s. 124-125.

Cardella L., Memorie storiche de' cardinali della Santa Romana Chiesa scritte da..., t. 8, Roma 1744.

Heilbron J. L., The Sun in the Church: Catedrals as Solar Observatories, Harvard 1999.

Jastrzębska E., Maria Kazimiera Sobieska wobec kandydatury syna Jakuba podczas bezkrólewia w świetle depesz ambasadora Polignaca (1696-1697), „Sobótka" 35 (1980), s. 351-354.

Kęder W., Jasna Góra wobec przemian politycznych w Rzeczypospolitej w latach 1661-1813, „Studia Claromontana” 13 (1993), s. 5-206.

Kęder W., Rola nuncjatury wiedeńskiej w ksztattowaniu polityki Stolicy Apos- 
tolskiej wobec Rzeczypospolitej w okresie pierwszego rozbioru, w: Veritati serviens. Księga pamiatkowa ojcu profesorowi Januszowi Zbudniewkowi, red. Jan Dzięgielewski [i in.], Warszawa 2009, s. 119-130.

Kęder W., Stolica Apostolska wobec Rzeczypospolitej w okresie konfederacji barskiej 1767-1773, Opole 2006.

Libiszowska Z., Ród Sobieskich w Europie po śmierci Jana III, „Sobótka” 35 (1980), s. 355-368.

Orszulik S., Polemika wokół kandydatury Sobieskich do korony w okresie bezkrólewia 1696/1697, „Sobótka” 35 (1980), s. 341-350.

Pastor L., „Storia dei papi dalla fine del medio evo", vol. 15 "Storia dei papi nel periodo dell' Assolutismo”. Vol. XV „Dall' elezione di Clemente XI sino alla morte di Clemente XII (1700-1740), Roma 1932.

Petrucelli della Gattina F., Histoire diplomatique des conclaves, vol. 4, Bruxelles 1866.

Pieroni Francini M., Da Clemente XI a Benedetto XIV; il caso Davia, „Rivista di Storia della Chiesa in Italia" 37 (1983), s. 438-471.

Squicciarini D., Nunzi apostolici a Vienna, Città del Vaticano 1998.

Weber Ch., Legati e governatori dello Stato Pontificio (1550-1809), Roma 1994. Publicazioni degli Archivi di Stato, Sussidi 7.

Wojtyska H. D., Acta Nuntiaturae Polonae, t. 1, Romae 1990.

\section{Streszczenie}

W latach 1696-1700 nuncjuszem w Rzeczypospolitej był Giovanni Antonio Davia, późniejszy kardynał. Na okres jego misji przypadło szereg skomplikowanych problemów wewnętrznych, jak i zewnętrznych, jakie trapiły Rzeczypospolitą: wojny tureckie, relacje katolików z innowiercami w Polsce, konflikty polityczne na Litwie, które zakończyły się wojną domową. Do bardzo interesujących należy wątek ewentualnego udziału Giovanniego Antonio Davii w elekcji na króla Polski Fryderyka Augusta Wettyna, którego panowanie miało tak fatalne skutki dla Rzeczypospolitej. Davia oskarżany był o sprzyjanie saskiej kandydaturze przez dyplomatów francuskich i ich stronników w Polsce, gdyż elektorowi saskiemu zawdzięczał uwolnienie bratanka Giovanniego Battisty z niewoli tureckiej, o co rodzina Daviów bardzo zabiegała. Nie ma bezpośrednich dowodów na złamanie przez nuncjusza Davię neutralności w elekcji, a pozostają jedynie oskarżenia przeciwników Wettyna.

Słowa klucze: kardynał Giovanni Antonio Davia, nuncjusz Giovanni Antonio Davia, kardynał Gianantonio de Via, dyplomacja Stolicy Apostolskiej 


\section{Cardinal Giovanni Antonio Davia (Gianantonio De Via) - nuncio in the Commonwealth (1696-1700)}

\section{Summary}

In the years 1696-1700, the nuncio in the Commonwealth was Giovanni Antonio Davia, later a cardinal. During his mission there were a number of complicated internal and external problems that plagued the Commonwealth: Turkish wars, relations between Catholics and infidels in Poland, and the political conflicts in Lithuania that ended in civil war. One of the most interesting topics is that of the possible participation of Giovanni Antonio Davia in the election of King Frederic Augustus Wettyn of Poland, whose reign had such terrible consequences for the Commonwealth. Davia was accused of supporting the Saxon candidacy by French diplomats and their supporters in Poland, because he owed the Saxon elector for the release of his nephew Giovanni Battista from Turkish captivity, which the Davia family sought. There is no direct evidence of the nuncio breaking the neutrality of the election, and only the accusations of Wettyn's opponents remain.

Key words: Cardinal Giovanni Antonio Davia, Nuncio Giovanni Antonio Davia, Cardinal Gianantonio de Via, diplomacy of the Holy See 